\title{
THE TRANS-TASMAN THERAPEUTIC PRODUCTS AUTHORITY: POTENTIAL AUSFTA IMPACTS ON SAFETY AND COST-EFFECTIVENESS REGULATION FOR MEDICINES AND MEDICAL DEVICES IN NEW ZEALAND
}

\author{
Thomas A Faunce, ${ }^{*}$ Kellie Johnston ${ }^{* *}$ and Hilary Bambrick ${ }^{* * * 1}$
}

\begin{abstract}
Australia and New Zealand have agreed in principle to the creation of a single agency for the regulation of pharmaceuticals and other therapeutic products in a trans-Tasman market. The Australia New Zealand Therapeutic Products Authority (ANZTPA) is being developed to replace both the Australian Therapeutic Goods Administration (TGA) and the New Zealand Medicines and Medical Devices Safety Authority (Medsafe). This article explores the possibility that the ANZTPA, by inheriting significant obligations imposed on the TGA under the Australia-United States Free Trade Agreement (AUSFTA), may significantly impact upon the regulation of medicines and medical devices (as well as blood products) in New Zealand. It explores the related legal obligations and their likely consequences for New Zealand: particularly quality, safety, efficacy and cost-effectiveness evaluation processes in this area, such as those of the New Zealand Pharmaceutical Management Agency (Pharmac).
\end{abstract}

* BA LLB (Hons) B Med PhD, Senior Lecturer, Medical School and College of Law. Director, Globalisation and Health Project Centre for Governance of Knowledge and Development, Regulatory Institutions Network, Australian National University.

** BSc (Hons) LLB (Hons) Research Associate, Globalisation and Health Project Centre for Governance of Knowledge and Development, Regulatory Institutions Network, Australian National University.

*** BSc BA (Hons) PhD, Research Fellow, National Centre for Epidemiology and Public Health, Australian National University.

1 Paper presented by first author at the Australia and New Zealand Society of International Law Annual Symposium "Free Trade Agreements: Boon or Bane for Australasia?" (Victoria University of Wellington, Faculty of Law, 28 August 2005). Statement of competing interests: The first author is Project Director of an Australia Research Council-funded investigation of the impact of international trade agreements on access to medicines in Australia. The second author is a research associate with that Project. 


\section{INTRODUCTION}

The Australia-United States Free Trade Agreement (AUSFTA) entered into force on 1 January 2005..$^{2}$ AUSFTA provisions (in annex $2 \mathrm{C}$ and related side letters) requiring alterations (particularly in the name of transparency and recognition of innovation) to Australia's internationally respected medicines cost-effectiveness pricing system, known as the Pharmaceutical Benefits Scheme (PBS), were a major concession to the United States brand-name pharmaceutical industry. Its representative organ, the Pharmaceutical Research and Manufacturers of America (PhRMA), had aggressively lobbied for and obtained a legislative mandate through the office of the United States Trade Representative (USTR), requiring United States trade negotiators to seek the "elimination" of such scientific pharmaceutical price evaluation structures. ${ }^{3}$ Yet it was not so much PBS government reimbursement that the United States pharmaceutical industry was targeting, as the scientific costeffectiveness evaluations performed by the Pharmaceutical Benefits Advisory Committee (PBAC). Picking up on these obligations, annex $2 \mathrm{C}$ of the AUSFTA also included provisions requiring Australia's Therapeutic Goods Administration (TGA) to initiate discussions with the United States Food and Drug Administration (FDA) about making "innovative" products more speedily available. $^{4}$

Chapter 17 of the AUSFTA (Intellectual Property) additionally contained a provision requiring the Australian TGA to "prevent" marketing approval for a generic medicine whenever a patent (of any type) was "claimed" over the original product. ${ }^{5}$ Concerns about the resultant amendments to the Therapeutic Goods Act 1989 (Cth) facilitating "evergreening" of soon to expire patents led to the passing of specific anti-evergreening legislation by the Australian Parliament. ${ }^{6}$

This article explores the question of whether the proposed joint scheme between Australia and New Zealand for the regulation of therapeutic products could inherit such AUSFTA obligations arising from annex $2 \mathrm{C}$ and chapter 17. It then considers how these might impact on the regulation of safety, efficacy and cost-effectiveness for medicines and medical devices (including blood products) in New Zealand.

2 Australia-United States Free Trade Agreement (18 May 2004) [2005] ATS 1. The full text, reports and fact sheets are available at Australian Government, Department of Foreign Affairs and Trade $<$ http://www.dfat.gov.au> (last accessed 10 August 2006) [AUSFTA].

3 Medicare Prescription Drug, Improvement, and Modernization Act of 2003 Pub L No 108-173, 117 Stat 2066 (2003); 21 USC Conference Agreement (Nov 21, 2003) 384; Trade Act of 2002 Pub L No 107-210, $\S 2102(b)(8)(D), 116$ Stat 933, 995 (2002).

4 AUSFTA, above n 2, annex 2C.4.

5 AUSFTA, above n 2, article 17.10.4.

6 T Faunce and others "Assessing the Impact of the Australia-United States Free Trade Agreement on Australian and Global Medicines Policy" (2005) 1 Globalisation and Health 1. 


\section{THE TRANS-TASMAN REGULATORY AGENCY}

Australia and New Zealand have agreed in principle to the creation of a single agency for the regulation of pharmaceuticals and other therapeutic products, administering a trans-Tasman market. The Australia New Zealand Therapeutic Products Authority (ANZTPA) is being developed to replace the Australian TGA and the NZ Medicines and Medical Devices Safety Authority (Medsafe). ${ }^{7}$ In broad terms its regulatory activities will include: 1) pre-marketing evaluation and assessment; 2) product licensing; 3) controls on manufacture; 4) post-market monitoring and surveillance; and 5) setting standards.

One curious feature of the documentation surrounding the establishment of this agency is a lack of substantial discussion whether obligations imposed on the Australia's TGA under the AUSFTA will be taken up entirely by the ANZTPA. In its submission to the Australian Joint Standing Committee on Treaties, Medicines Australia (a lobby organisation for brand-name pharmaceutical manufacturers located in Australia) noted the differences in intellectual property protection between New Zealand and Australia and submitted that any resultant ambiguities should not be resolved in favour of the "weaker" New Zealand laws. ${ }^{8}$ Medicines Australia went further, suggesting that various measures should be included in the treaty to ensure Australia's stronger intellectual property provisions apply. ${ }^{9}$ Concerns about precisely this possibility were expressed by the New Zealand Pharmaceutical Management Agency (Pharmac) and re-iterated by New Zealand's Health Committee in its report on the ANZTPA: ${ }^{10}$

Pharmac noted a number of concerns about the joint agency proposal, including possible increases in the cost of generic drugs, particularly for small market products, and possible increases in patent terms of medicines. In its written submission to us, Pharmac noted that unless rules were very carefully drafted, the cost of these latter increases as a flow-on effect of the free trade agreement between Australia and the United States of America could amount to between $\$ 85$ and $\$ 135$ million over 3 years.

There are eight main areas of concern regarding the application of the AUSFTA to the ANZTPA that will be addressed in turn.

7 See Australia - New Zealand Agreement for the Establishment of a Joint Scheme for the Regulation of Therapeutic Products (10 December 2003) [2003] ATNIF 22 [Australia-NZ Agreement]; ANZTPA $<$ http://www.anztpa.org $>$ (last accessed 10 August 2006).

8 Medicines Australia "Submission to the Joint Standing Committee on Treaties, Parliament of Australia: Inquiry into the Agreement Between the Government of Australia and the Government of New Zealand for the Establishment of a Joint Scheme for the Regulation of Therapeutic Products" (30 March 2004) 2, available at $<$ http://www.aph.gov.au $>$ (last accessed 18 August 2006).

9 Medicines Australia, above n 8, 2.

10 Health Committee "International Treaty Examination of the Agreement Between the Government of New Zealand and the Government of Australia for the Establishment of a Joint Scheme for the Regulation of Therapeutic Products" (June 2004) 3. 


\section{A "Linkage" Obligations and Evergreening}

The first area of concern involves the question of whether the "evergreening" notification provisions in article 17.10.4 of the AUSFTA will apply to the ANZTPA, as they do now to the TGA due to implementing changes to the Therapeutic Goods Act 1989 (Cth).

Article 17.10.4 of the AUSFTA is the now notorious "evergreening" provision. Under article 17.10.4(a), "marketing approval" by Australia's TGA of a generic drug must be "prevented" when any type of patent is "claimed" by a brand-name manufacturer that has not "consented or acquiesced" to the generic market entry. Article 17.10.4(b) creates an obligation for a brand name patent owner to be notified of any impending generic market entry. Australia passed amendments to its Therapeutic Goods Act 1989 (Cth) late in 2004, ${ }^{11}$ establishing a certification process, which were designed to implement these obligations.

The "linkage" of marketing approval and patent status required by article 17.10 .4 is not an obligation arising from the Agreement on Trade Related Aspects of Intellectual Property Rights (TRIPS) of the World Trade Organization (WTO). ${ }^{12}$ It appears in the AUSFTA to cover only prescription medicines, but was originally interpreted by Australia's TGA to also cover over-thecounter and herbal medicines (although further legislation has rectified this misunderstanding).

Article 17.10.4 pursues PhRMA's global agenda, repeatedly stated on the USTR "Trade Watch" list, of ensuring pharmaceutical marketing approval is linked with patent validity. ${ }^{13}$ Canada was made to implement a similar provision in its Patented Medicines (Notice of Compliance) Regulations in 1993 after entering the North American Free Trade Agreement (NAFTA). Ever since, the Canadian Office of Patented Medicines and Liason, a body with specialist patent and public health expertise, has been closely scrutinising the inhibition by this mechanism of rapid entry of cheap generic medicines to the market. ${ }^{14}$

Classic "Hatch-Waxman" evergreening, as imposed on Canada after NAFTA, involves a brand name pharmaceutical company gaining regulatory notification of impending generic entry and then seeking an injunction to gain extra patent life and royalties, usually in relation to a "blockbuster"

11 Therapeutic Goods Act 1989 (Cth), ss 26A and 26B.

12 Agreement on Trade-Related Aspects of Intellectual Property Rights (15 April 1994) 1869 UNTS 299; (1994) ILM 81 [TRIPS].

13 P Drahos and others "Pharmaceuticals, Intellectual Property and Free Trade: The Case of the US-Australia Free Trade Agreement" (2004) 22 Prometheus 243.

14 Interviews conducted by Dr Faunce and Professor Drahos with senior members of the Office of Patented Medicines and Liason in Ottawa, Canada (September 2005) under Australian Research Council Grant DP 0556635 . 
high sales volume drug. ${ }^{15}$ There are, however, now many other techniques of "evergreening". ${ }^{16}$ One approach is to cluster multiple, even hundreds of, patents around each molecule covering not only its active compound, but also its uses and delivery systems. In time, this strategy may extend to patenting combinations of drugs (for example aspirin with statins), or combinations of a drug and a genetic test.

Another technique involves licensing agreements between the brand name owners of a soon-toexpire pharmaceutical "blockbuster" patent and generic companies (creating a so-called "authorised" generic) and, increasingly, take-overs of generic companies by brand name manufacturers. ${ }^{17}$ The brand name pharmaceutical industry also extends its patent monopolies by driving out generic competition; for example by lobbying governments to implement mandatory price reductions on generic manufacturers that reduce their profit margins.

The ANZTPA will be established by Australia as a body corporate under Australian legislation to administer the joint scheme in both countries. ${ }^{18}$ Under the joint scheme there will only be one application for marketing approval and one licence necessary for both Australia and New Zealand. The obvious question is whether the ANZTPA will become a vehicle whereby New Zealand will be subjected to the AUSFTA article 17.10.4 "evergreening" linkage requirements currently imposed on Australia's TGA.

Medicines Australia appears to have contemplated just such an outcome. In its submission to the Australian Joint Standing Committee on Treaties Inquiry into the ANZTPA, Medicines Australia expressed concern that "the dual country licence may also exacerbate patent infringements that some of our members have experienced with products protected by patent being supplied by a generic company in contravention of the Patents Act". 19

To combat this, Medicines Australia proposed the ANZTPA administer a measure similar to that outlined in article 17.10.4 of the AUSFTA, where the patent holder is notified by ANZTPA

15 This notification requirement was introduced to the United States in the Drug Price Competition and Patent Term Restoration Act of 1984 Pub L No 98-417, 98 Stat 1585 (1984), known colloquially as the HatchWaxman Act.

16 For a discussion of the various methods of evergreening employed in the United States, see National Institute for Health Care Management "Changing Patterns of Pharmaceutical Innovation" (May 2002) $<$ www.nihcm.org> (last accessed 10 August 2006).

17 See Oligopoly Watch <http://www.oligopolywatch.com/stories/2004/02/17/pharmaceuticals.html > (last accessed 10 August 2006). This is a continually updated site dealing with mergers in the pharmaceutical industry.

18 Australia-NZ Agreement, above n 7, article 5.4.

19 Medicines Australia, above n 8, 3 
regulators when they received an application to register a generic product. ${ }^{20}$ In response, the Australian Government stated that: ${ }^{21}$

We are focusing our attention on the regulatory aspects of the quality, safety and efficacy of therapeutic products rather than on the patent aspects, but we think that some of the measures that we will have in place that will deal with the safety issues in particular will meet some of the needs and concerns of Medicines Australia.

This clarification by the Australian Government unfortunately still leaves the application of the provisions of article 17.10.4 of the AUSFTA to the ANZTPA unclear. The text of the ANZTPA Agreement provides that the Ministerial Council (comprising the Australian and New Zealand Ministers for Health) may make rules for the purposes of prescribing "notification requirements", in respect of the manufacture, supply, import, export or promotion of therapeutic products. ${ }^{22}$ While no rules have been made to date, the potential clearly exists for the notification of generic application provisions under the AUSFTA to also apply to the ANZTPA. This possibility was recognised in New Zealand even before the AUSFTA was finalised: ${ }^{23}$

[R]estrict[ion] or delay [in] access to cheap, generic medicines in New Zealand ... is further exacerbated by the proposed free trade deal between Australia and the United States of America, which contains provisions that are designed to add further restrictions on the approval of generic medicines by the joint agency. These restrictions will make it more difficult for generic medicines to make it to the market, pushing up costs for Pharmac and hence the New Zealand taxpayer and reducing access to new medicines.

It is possible (but operationally difficult) to specify that the measures required by article 17.10.4 of the AUSFTA could be "carved out" to operate only with respect to Australia under the ANZTPA. Most likely, however, New Zealand may well be subjected to these potentially "evergreening" obligations by default under the ANZTPA and generic manufacturers in both countries will be required to notify patent holders upon application for approval to market a generic product in either Australia or New Zealand.

Delayed entry of generic drugs, as a result of the brand name pharmaceutical patent "evergreening" strategies facilitated by articles such as article 17.10.4, could have a significant

20 Medicines Australia, above n 8, 3 .

21 Jeffrey Ibbotson "Evidence to Joint Standing Committee on Treaties, Parliament of Australia: Inquiry into the Agreement Between the Government of Australia and the Government of New Zealand for the Establishment of a Joint Scheme for the Regulation of Therapeutic Products Parliament of Australia" (Canberra, 10 May 2004) 3.

22 Australia-NZ Agreement, above n 7, art 9.

23 Health Committee, above n 10, 12. 
impact on the viability of a nation's generic pharmaceutical industry. The cost, for example, to the PBS and Australian taxpayers of an "evergreening"-induced 24 month delay to generic competition after brand name patent expiry over certain key classes of "blockbuster" pharmaceuticals has been estimated to be $\mathrm{A} \$ 1.1$ billion over four years. ${ }^{24}$ Delayed entry of generic drugs will also affect the prices of pharmaceuticals purchased by private and public hospitals and over-the-counter medicines which are not covered by government subsidies or safety nets. The end result is likely to be higher pharmaceutical costs in New Zealand. Public hospitals in New Zealand are also likely to face substantial rises in expenditure on their medicines budgets. ${ }^{25}$

An AUSFTA supervising committee (and possibly the Medicines Working Group) will oversee implementation of the notification provisions of article 17.10.4. Its recommendations may mean that in time this obligation will apply not only to pharmaceuticals, but also to over-the-counter and complementary medicines. Previously, New Zealand has not required pre-market approval for complementary medicines (often termed dietary supplements in New Zealand and regulated under food legislation). Under the Joint Regulatory Scheme, however, these products will be regulated by the ANZTPA. This has been one of the most controversial aspects of the Joint Regulatory Scheme in New Zealand. The absence of an existing system for the regulation of complementary medicines in New Zealand will make it difficult for New Zealand to resist the blanket introduction of the current Australian arrangements for these products, including the "evergreening" notification provisions.

A related question will be whether the Australian so-called "anti-evergreening" provisions introduced with the AUSFTA implementing legislation will also apply to the ANZTPA and to New Zealand. This legislation introduced new sections 26C and 26D in the Therapeutic Goods Act 1989 (Cth). The "anti-evergreening" amendments allow the Commonwealth Attorney-General to join an application for an injunction by a brand name patent holder against a generic medicines manufacturer and to claim damages where the injunction has caused a price rise under the PBS. While it is unlikely that any generic company will use these provisions to litigate due to financial constraints and cross-ownership in the industry, the existence of the "anti-evergreening" amendments may prove valuable in a likely trade dispute with the United States over the PBS. In the event of a textual ambiguity in the AUSFTA, recourse may be had to supplementary materials to determine obligations contained in the agreement under article 32 of the Vienna Convention on the Law of Treaties. ${ }^{26}$ Australia may be able to use the "anti-evergreening" amendments as evidence

24 B Lokuge, T Faunce and R Denniss "A Backdoor to Higher Medicine Prices? Intellectual Property and the Australia-US Free Trade Agreement" (Australia Institute, Canberra, 2003) 14.

25 See Lokuge, Faunce and Denniss, above n 24. While this analysis relates to Australia, the same principles apply to New Zealand.

26 AUSFTA, above $\mathrm{n}$ 2, art 21.9.2. This article directly imports into the AUSFTA the rules of treaty interpretation contained in articles 31 and 32 of the Vienna Convention on the Law of Treaties (23 May 1969) 1155 UNTS 331; 8 ILM 679. 
that it had a legitimate expectation that the AUSFTA, and article 17.10.4 in particular, would not increase medicines prices under the PBS. Unless New Zealand introduced similar legislation at the time it entered into the Joint Regulatory Scheme, it is unclear whether it could take advantage of these Australian "anti-evergreening" amendments.

The United States has clearly signalled its disapproval of the Australian "anti-evergreening" amendments, stating their belief that they "impose a potentially significant, unjustifiable and discriminatory burden on the enjoyment of patent rights". ${ }^{27}$ However, in challenging the amendments on the basis that they are discriminatory as to the field of technology and thus a breach of article 27.1 of the TRIPS, the United States is on weak ground. Immediately prior to finalising the AUSFTA negotiations, the United States legislature passed its Medicare Prescription Drug Improvement and Modernisation Act 2003. Included in section 1101 of that Act was a complicated process of early declaratory relief to assist remedying the problem of brand name pharmaceutical patent "evergreening". This implemented a specific recommendation in the report of the United States Federal Trade Commission (FTC) in 2002 that only one "evergreening" injunction against a potential generic market entrant be permitted per product. ${ }^{28}$

At the recent inaugural meeting of the Joint Committee, set up under the AUSFTA to review the operation of the agreement, Australian Trade Minister Mark Vaile resisted any pressure to revoke the anti-evergreening amendments, maintaining the Australian Government's stance that for the "anti-evergreening" amendments to be withdrawn the United States and the pharmaceutical lobby "would have to prove that those amendments are being commercially detrimental". ${ }^{29}$ However, $\mathrm{Mr}$ Vaile did note after the meeting that: ${ }^{30}$

27 Robert Zoellick, United States Trade Representative Ambassador, to Mark Vaile, Australian Minister for Trade (17 November 2004) Letter, available at <http://www.ustr.gov> (last accessed 10 August 2006) [Zoellick-Vaile Letter].

28 Federal Trade Commission Generic Drug Entry Prior to Patent Expiration: An FTC Study (Washington, 2002). The panel in Canada-Patent Protection of Pharmaceutical Products (2000) WT/DS114/R para 7.92 (Panel, WTO) held that TRIPS article 27 "does not prohibit bona fide exceptions to deal with problems that may exist only in certain product areas".

29 "FTA will Push Drug Prices Up: ALP" (3 January 2006) ABC News Online $<$ http://www.abc.net.au> (last accessed 10 August 2006). Research interviews conducted by Dr Faunce and Professor Drahos with representatives of the Australian Pharmaceutical Industry (2005) under Australian Research Council Grant DP0556635 found no evidence of such detriment.

30 Mark Vaile, Deputy Prime Minister and Minister for Trade, and Rob Portman, United States Trade Representative Ambassador (Office of the United States Trade Representative, Washington DC, 7 March 2006) Joint Press Conference, available at $<\mathrm{http}: / /$ www.trademinister.gov.au $>$ (last accessed 10 August 2006) [Joint Press Conference]. 
We maintain an ongoing dialogue with industry in Australia, and just remember that Medicines Australia, which is the peak body in Australia, is very closely linked with some common members to Pharma here in the US, and Government remains in close dialogue with them.

\section{B Fast Tracking "Innovative" Medical Products}

Secondly, of significant concern for both the efficiency of the ANZTPA and the ongoing fiscal benefits flowing from New Zealand's Pharmac and the Pharmaceutical Schedule it manages, is a specific obligation imposed on Australia's TGA by annex $2 \mathrm{C}(4)$ of the AUSFTA. Under the heading "Regulatory Co-Operation" it requires: ${ }^{31}$

The Parties shall seek to advance the existing dialogue between the Australian Therapeutic Goods Administration and the United States Food and Drug Administration with a view to making innovative medical products more quickly available to their nationals.

This provision appears likely to oblige the ANZTPA (as the inheritor organisation of the Australian TGA) to engage in dialogue with the United States FDA on the expedition of marketing approval for "innovative" medical products. This provision will facilitate rapid market access for therapeutic products, ensuring their patent rent-earning capacity is as long as possible. It may, however, compromise the ability of the ANZTPA to do thorough reviews of emerging new medical technologies (such as nanomedical products). The United States FDA, for example, has recently come under intense public and governmental scrutiny for perceived inadequacies and conflicts of interest arising from its willingness to respond to such "fast track" pressures. ${ }^{32}$

AUSFTA annex 2C(4) may also become a Trojan Horse whereby pharmaceutical interests begin to push for "innovation" changes to New Zealand's Pharmac processes, such as tendering and pooled procurement of frequently used pharmaceuticals, without the necessity of having to grant reciprocal trade concessions. In the ongoing corporate lobbying of government that follows such obligations, generic medicines (which have difficulties satisfying "innovation" criteria) are often marginalised.

Pharmac was originally established under the Health and Disabilities Services Act 1993 (now the Public Health and Disability Act 2000) with the specific purpose of securing for "eligible people in need of pharmaceuticals, the best health outcomes that are reasonably achievable from pharmaceutical treatment and from within the funding provided". ${ }^{33}$ Pharmac, with the assistance of independent medical experts on the Pharmacology and Therapeutics Advisory Committee (PTAC) and its specialist sub-committees, manages, on cost-effectiveness grounds set out in guidelines, a federal formulary, known as the Pharmaceutical Schedule. Patients and their advocacy groups have

31 AUSFTA, above n 2, annex 2C(4) (emphasis added).

32 W A Ray and C M Stein "Reform of Drug Regulation Beyond an Independent Drug-Safety Board" (2006) 354 New Eng J Med 194, 194-201.

33 Public Health and Disability Act 2000, s 47. 
input into Pharmac's listing decisions through a Consumer Advisory Committee. One of Pharmac's major advances involves the use of tendering for low cost generic medicines. ${ }^{34}$ In determining whether a product should be listed, Pharmac must consider: the health needs of people within New Zealand; the existing alternative medicines available; the clinical benefits and risks of pharmaceuticals; the cost-effectiveness of using pharmaceuticals; the budgetary impacts of listing a certain product and the direct cost to the health service user. ${ }^{35}$ In determining the subsidy at which a product is listed, Pharmac may use any one of a number of pricing mechanisms, including reference pricing, listing contracts, rebate arrangements, bundling arrangements, tendering and parity pricing. ${ }^{36}$

Recent speculation that Pharmac tendering-style arrangements would be introduced in Australia in order to contain the cost of the PBS met with strong criticism from the pharmaceutical industry in both New Zealand and Australia. ${ }^{37}$ Pharmac is likely to be such a target simply because of its success. Between 1998 and 2002, the average annual change in pharmaceutical expenditure in New Zealand was 1.4 per cent, compared to 14.5 per cent in the United States, 9.7 per cent in the United Kingdom and 12.1 per cent for Australia. ${ }^{38}$

Supporting this possibility is the fact that AUSFTA annex $2 \mathrm{C}(1)(\mathrm{c})$ emphasises "timely and affordable access to innovative pharmaceuticals" through "transparent, expeditious, and accountable procedures". This suggests an explicit link between annex $2 \mathrm{C}(1)(\mathrm{c})$ ("timely and affordable access to innovative pharmaceuticals") and annex $2 \mathrm{C}(4)$ (dialogue on "making innovative medical products more quickly available").

Alternatively, annex 2C(4) also opens the door for the United States FDA, should it so wish, to commence discussions with ANZTPA representatives on introducing a new system for recognising pharmaceutical innovation that links "innovation" to community cost effectiveness in comparison with existing alternate drug therapies. This scenario could arise from ANZTPA incorporating for the purposes of annex $2 \mathrm{C}(4)$, the unusual definition of "innovation" specified in annex $2 \mathrm{C}(1)$.

34 New Zealand Pharmaceutical Management Agency (Pharmac) Operating Policies and Procedures (3 ed, Wellington, January 2006) para 3.2.

35 Pharmac, above n 34, para 2.2.

36 Pharmac, above n 34, para 3.2 .

37 P Mackay "NZ way no way for Australia's PBS" (14 February 2006) Pharma in Focus $<$ http://www.pharmainfocus.com.au> (last accessed 10 August 2006); Medicines Australia "Warning to Government from Biotech on PBS Changes" (30 January 2006) Press Release.

38 New Zealand Pharmaceutical Management Agency Annual Review (Wellington, 2002) 12; JM Tordoff, PT Norris, DM Reith "Managing Prices for Hospital Pharmaceuticals: A Successful Strategy for New Zealand?" (2005) 8 Value in Health 201, 202. 
Annex $2 \mathrm{C}(1)$ commences with a statement of primary or overarching principle: "The Parties are committed to facilitating high quality health care and continued improvements in public health for their nationals". The article then continues to enumerate a series of subsidiary principles: ${ }^{39}$

In pursuing these objectives, the Parties are committed to the following principles:

a) the important role played by innovative pharmaceutical products in delivering high quality health care;

b) the importance of research and development in the pharmaceutical industry and of appropriate government support, including through intellectual property protection and other policies;

c) the need to promote timely and affordable access to innovative pharmaceuticals through transparent, expeditious, and accountable procedures, without impeding a Party's ability to apply appropriate standards of quality, safety, and efficacy; and

d) the need to recognize the value of innovative pharmaceuticals through the operation of competitive markets or by adopting or maintaining procedures that appropriately value the objectively demonstrated therapeutic significance of a pharmaceutical.

Inserting a corporate-defined conception of "innovation" as a major policy driver into the ANZTPA and perhaps into Pharmac would undoubtedly compromise policy principles that have been more thoroughly tested by democratic processes, such as equity and social justice.

However there is some evidence that "innovation" has been set in annex 2C(1) of the AUSFTA in a context which emphasises objective proof of the social value of innovation. Annex $2 \mathrm{C}(1)$ (a), for example, links "innovation" with "high quality health care." Annex 2C(1)(c) sets pharmaceutical innovation within the context of "affordability" and "accountability" and annex $2 \mathrm{C}(1)(\mathrm{d})$ creates a commitment by the parties that recognition of innovative pharmaceuticals may involve either "competitive markets" (hence the necessity for collusion and other anti-competitive practices in the pharmaceutical industry to be policed by regulators) or "procedures that appropriately value the objectively demonstrated therapeutic significance" of a pharmaceutical (the scientific approach to cost-effectiveness evaluation prior to government reimbursement).

While brand-name pharmaceutical industry rhetoric frequently links its new "innovative" products with improved public health, there is very little, if any, research that establishes that link. ${ }^{40}$ Much genuine innovation in medicines development continues to arise from public funded

39 AUSFTA, above n 2, annex 2C(1) (emphasis added).

40 See J Abraham and T Reed "Progress, Innovation and Regulatory Science in Drug Development: The Politics of International Standard Setting" (2002) 32 Soc Stud Sci 337. 
university research and development expenditure and is supported by specific government programs. ${ }^{41}$ Tax concessions have also been important stimulators of pharmaceutical innovation. ${ }^{42}$

However, because they minimise costs of pharmaceuticals for taxpayers in Australia and New Zealand, cost-effectiveness and reference pricing mechanisms are constantly lobbied against by brand-name pharmaceutical multinationals. The United States government was recently prohibited by pharmaceutical company-sponsored legislation from using its bulk buying power to bargain down drug costs. ${ }^{43}$ PhRMA, throughout the AUSFTA negotiations, frequently criticised reference pricing and cost-effectiveness aspects of the PBS as a "trade distorting, abusive, or discriminatory price control". ${ }^{44}$ Their numerous lobbyists convinced the United States Government to believe and argue that a viable strategy medicines policy in the United States and Australia would ensure consumers in all countries, not just the United States, paid for the high research and development costs required to make "innovative" pharmaceuticals. ${ }^{45}$ The AUSFTA annex $2 \mathrm{C}(1)$ principles could influence medicines policy in New Zealand through the regional influence of the Australian pharmaceutical market and regulatory system, independent of any connection with the ANZTPA. If industry lobbyists in New Zealand, for example, are able to point to "innovation" changes in Australia's PBAC processes it will facilitate the New Zealand government's concession to making similar changes to Pharmac's processes.

A major problem here is that the members of PhRMA have yet to disclose the marginal cost of production for each allegedly "innovative" drug. ${ }^{46}$ Further, reliable evidence now suggests that United States pharmaceutical companies spend two to three times more on marketing, administration and lobbying than on research and development, and their profits are approximately twice such costs. ${ }^{47}$ The Australian Productivity Commission has confirmed that the largest price differences between Australia and the United States are for aggressively marketed non-innovative "me-too" pharmaceuticals. These drugs, though marketed as innovative, generally only involve

41 Pharmaceutical Industry Investment Program < http://www.industry.gov.au> (last accessed 16 March 2006).

42 Australian Government "Backing Australia's Ability: Building Our Future through Science and Innovation" (2004), available at <http://backingaus.innovation.gov.au> (last accessed 10 August 2006).

43 See M Angell "Excess in the Pharmaceutical Industry" (2004) 171 CMAJ 1451.

44 Pharmaceutical Research and Manufacturers of America National Trade Estimate Report on Foreign Trade Barriers 2004 (Submission, 12 December 2005) 6.

45 T Colebatch "Bush Wants End to Medicine Subsidies" (24 October 2003) The Age Melbourne, 5.

46 National Science Foundation Research and Development in Industry: 2000 (NSF 03-318, Arlington (VA), 2003).

47 Families USA Foundation Profiting from Pain: Where Prescription Drug Dollars Go (No 02-105, Washington DC, 2002) 3-4. The "free rider" argument put forward by the pharmaceutical industry to justify its quest to remove price controls in foreign countries was countered recently in Donald W Light and Joel Lexchin "Foreign free riders and the High Price of United States medicines" (2005) 331 BMJ 958. 
small molecular variations and are aggressively promoted to capture lucrative niche markets. PBS prices for new drugs providing genuine benefit are much closer to United States prices. ${ }^{48}$

However, many may believe such concerns are unfounded. Australian Trade Minister Mark Vaile said, for example, at the conclusion of the AUSFTA negotiations, that "the PBS, in particular the price and listing arrangements that ensure Australians' access to quality, affordable medicines, remains intact." 49

At a press conference following the recent meeting of the Joint Committee, the Australian Trade Minister reignited concerns about the effect of "innovation" lobbying on the cost of medicines under the PBS when he stated: ${ }^{50}$

We do maintain though, at this stage, at the 12 or 14 month point, that in recognition of the core principle that we both agree on in this area and that is recognising the value of innovation and the importance of ongoing innovation as far as pharmaceuticals are concerned as the fundamental central principle in what we're doing. We continue to monitor a number of different areas in the operations of our system in Australia, our PBS, or as you call it here in the United States, our formulary.

This sentiment echoes that expressed by USTR Ambassador, Rob Portman, who stated at the same press conference: ${ }^{51}$

And we had a very positive discussion in terms of what we agree on, which is that innovation transparency ought to be key, not just in terms of pharmaceutical policy but overall in terms of intellectual property.

Describing "innovation" as the "fundamental central principle" exacerbates concerns that such a focus for health care policy is incompatible with existing Australian and New Zealand public health policy. That policy is based on more established democratic principles such as equity and distributive justice, as reflected in mechanisms such as reference pricing, tendering and the exercise of scientific cost-effectiveness evaluation, linked with monopsony buying power to bargain lower prices for federal formularies. The Australian Government, however, has recently been investigating the introduction of New Zealand Pharmac-style tendering processes for low cost generic medicines as a PBS cost-saving measure. ${ }^{52}$

48 See Productivity Commission International Pharmaceutical Price Differences: Research Report (Melbourne, 2001).

49 M Vaile "Free Trade Agreement with the United States" (8 February 2004) Press Release.

50 Mark Vaile, Deputy Prime Minister and Minister for Trade, in Joint Press Conference, above n 30.

51 Rob Portman, United States Trade Representative Ambassador, in Joint Press Conference, above n 30.

52 See T A Faunce, H Lofgren, K Harvey, K Johnston "Tendering for Low Cost Generics in Australia" (2004) 87 Health Issues 26. 
The potential here for gradual dismantling of the PBS price setting mechanisms through the AUSFTA has implications beyond medicines policy in Australia. It has the capacity to set a precedent for all trading partners of the United States, including New Zealand.

\section{Direct to Consumer Advertising}

The third problem for the ANZTPA is that the preferred pharmaceutical industry model of reduced scientific evaluation of cost-effectiveness and increased direct-to-consumer advertising (DTCA) may be facilitated. Annex 2C(5) of the AUSFTA permits a pharmaceutical manufacturer to disseminate pharmaceutical information via the internet, for example, via links on sites frequently used by Australian patients. This appears to be a PhRMA strategy to begin the process of lobbying for DTCA in Australia. DTCA is legal in the United States and New Zealand, but not in Australia. It has been associated with a substantial increase in usage of the products which are often not in accord with clinical best-practice. ${ }^{53}$ In the United States, pharmaceuticals can be marketed directly to the consumer, provided they have been shown to be safe and effective in animal and human studies when compared with a placebo (effectively nothing) ${ }^{54}$ Industry can increase revenue simply by increasing advertising to doctors and direct to patients.

This is an area of major policy difference in Australasia, with New Zealand permitting DTCA and Australia prohibiting it, on prescription medicines. However, recognising the controversy surrounding DCTA and in response to the forthcoming establishment of the joint regulatory agency, New Zealand called a review of current policy. ${ }^{55}$ The review sought industry and community input on the impact of DCTA, particularly in the areas of the quality use of prescription medicines, provision of consumer information, cost-effectiveness and standards of advertising. ${ }^{56}$

Concerns have been expressed by the Australian Medical Association that the creation of a joint regulatory scheme between Australia and New Zealand to harmonise regulatory practices between the two countries could result in DTCA occurring in Australia. ${ }^{57}$ Such concerns are further

53 See B Mintzes and others An Assessment of the Health System Impacts of Direct-to-Consumer Advertising of Prescription Medicines (DTCA) (Centre for Health Services and Policy Research, The University of British Columbia, Vancouver, 2002).

54 The United States FDA regulates DTCA under the authority of the Federal Food, Drug and Cosmetic Act 21 USC $\S 502(n)$. The Act sets out general standards for the FDA's regulation. Federal regulations further describe the standards for advertising; see 21 CFR $\S 202$.

55 Ministry of Health Direct-to-Consumer Advertising of Prescription Medicines in New Zealand: Consultation Document (Wellington, 2006).

56 Ministry of Health, above n 55, 1.

57 Australian Medical Association "Submission to the Joint Standing Committee on Treaties, Parliament of Australia: Inquiry into the Agreement between the Government of Australia and the Government of New Zealand for the Establishment of a Joint Scheme for the Regulation of Therapeutic Products" (30 April 2004), available at <http://www.aph.gov.au> (last accessed 18 August 2006) . 
exacerbated by the desire of New Zealand to enter into a free trade agreement with the United States in which the legality of DTCA would almost certainly be entrenched, and increases pressure for New Zealand to maintain the status quo, regardless of the findings of the review.

Recently, as part of the implementation of the joint regulatory scheme, the Australian and New Zealand Governments developed the Australia New Zealand Therapeutic Products Advertising Code to regulate the advertising, both branded and unbranded, of therapeutic products in all forms of media, including the internet. ${ }^{58}$ While recognising the prohibition in Australia on DTCA of prescription medicines, the Code sets out requirements for advertising of each type of therapeutic product and an approvals process for DTCA. The existence of the Code and its application to prescription medicines in New Zealand and to internet advertising in Australia may contribute to pressure on Australia to harmonise with the United States and New Zealand and permit DTCA of prescription medicines. The main problem for New Zealand, however, may be that including annex $2 \mathrm{C}(5)$ in the ANZTPA could effectively entrench DTCA in the New Zealand system, even if the review findings could convince the New Zealand Government that evidence showed it was harming public health or public expenditure on pharmaceuticals.

\section{Cost-Recovery and Independence}

The fourth problem, though one chiefly exacerbating the lobbying effects mentioned earlier, involves considerations of whether the ANZTPA will seek full cost recovery from industry, as does Australia's TGA and the United States FDA. While the Australian Government is to provide funding for the establishment and implementation of the joint scheme and New Zealand is to contribute to the financial requirements of the ANZTPA, the Australian and New Zealand Governments anticipate the ANZTPA will operate on a full cost recovery basis within 5 years. ${ }^{59}$ The problems faced by the United States FDA in the recent Vioxx scandal reveal how difficult it may become for the ANZTPA to operate as an effective regulator if it is not actually and perceived to be at full arms' length from industry pressure. ${ }^{60}$

In addition, full cost recovery may increase the cost of gaining regulatory approval for therapeutic products with the effect of raising barriers to entry to the market. Pharmac submitted

58 Australia New Zealand Therapeutic Products Authority "Australia New Zealand Therapeutic Products Advertising Code" (July 2005), available at $<$ http://www.anztpa.org $>$ (last accessed 10 August 2006).

59 Joint Standing Committee on Treaties, Parliament of Australia "Inquiry into the Agreement Between the Government of Australia and the Government of New Zealand for the Establishment of a Joint Scheme for the Regulation of Therapeutic Products" (Report 62: Treaties Tabled on 30 March 2004, Canberra, August 2004) 2.44, available at <http://www.aph.gov.au> (last accessed 18 August 2006).

60 R Horton "Vioxx, the Implosion of Merck, and Aftershocks at the FDA" (2004) 364 Lancet 1995, 1995. 
that the high fees to be imposed by the ANZTPA in order to fully recover its costs may restrict or delay access to cheap, generic medicines. ${ }^{61}$

\section{E The TRIPS-PLUS Intellectual Property Ratchet}

Chapter 17 of the AUSFTA includes a variety of provisions apparently designed to protect the interests of United States pharmaceutical multinationals in ways which go further than the TRIPS agreement. This has led these provisions to be characterised as "TRIPS-PLUS", although in terms of their impact on social welfare and public health "TRIPS-MINUS" would probably be a more apt descriptor. Australia may decide to "share the pain" and expose regional neighbours to similar provisions in its bilateral agreements. The United States is also highly likely to seek to include similar provisions in other bilateral agreements it enters into, for example, with South Korea and Malaysia. Such provisions could become part of the United States attempt to ratchet up global intellectual property protection via multiple bilateral and regional trade agreements and ultimately a renegotiation of TRIPS. ${ }^{62}$ Further, the availability of strong intellectual property protection for pharmaceuticals in Australia allows the pharmaceutical industry to exert pressure on governments throughout the region to provide equivalent intellectual property protection with the threat of moving their manufacturing facilities to Australia.

There are several areas of intellectual property protection that the United States was unsuccessful in securing in the TRIPS negotiations. However, these have been included in the AUSFTA and may have an impact on medicines policy in New Zealand, either through a TRIPS renegotiation, through a New Zealand-United States free trade agreement, or industry lobbying pressure.

The AUSFTA prohibits parallel importation under article 17.9.4. This was something that the United States certainly had not managed to achieve in negotiations at the multilateral level. This proscription represents a manifest circumvention of the Doha Declaration on the TRIPS Agreement and Public Health ${ }^{63}$ which had confirmed that each WTO member may establish its own regime of exhaustion of intellectual property rights, and thus that such parallel importation could not be

61 Health Committee, above n 10, 12.

62 Article 4 of TRIPS provides that with respect to intellectual property any advantage, favour, privilege or immunity granted by a Member to the nationals of any other country shall be accorded immediately and unconditionally to the nationals of all other Members. Thus, the standards of intellectual property protection agreed to under the AUSFTA must be granted to all WTO members. When a sufficient number of WTO members have increased intellectual property protection above the TRIPS minimum, an attempt to put the TRIPS standards back on the negotiating agenda is likely to be successful.

63 WTO Ministerial Conference Declaration on the TRIPS Agreement and Public Health (WT/MIN(01)/DEC/2, 2001). 
considered a violation of TRIPS. ${ }^{64}$ Prohibition of parallel importation makes little sense in terms of free trade policy as it merely protects an industry from a competitive advantage obtained by mechanisms such as government reimbursement based on cost-effectiveness evaluations. The fear of parallel importation has been a major factor in the reluctance of the international pharmaceutical industry to allow the manufacture of cheap anti-retrovirals in Africa.

Compulsory licensing of pharmaceuticals is restricted under article 17.9.7 of the AUSFTA to a standard more stringent than that applying in TRIPS. Having failed in multilateral fora to restrict this exemption to specific diseases like HIV/AIDS or malaria, PhRMA through the USTR, in article 17.9.7, achieved a restriction on compulsory licensing to "TRIPS-PLUS" standard of "national emergency, or other circumstances of extreme urgency". 65 It would be imprudent to claim that this is not a substantial restriction on compulsory licensing, given that government policy decisions in this area will undoubtedly be subjected to lobbying from industry if they are perceived to threaten market share. Brazil provides a good example of a country that has used the TRIPS compulsory licensing exception to good effect when faced with a public health problem. This restriction in the AUSFTA creates the bizarre possibility that Australian domestic public health policy may in the future be evaluated by a three person panel of trade lawyers, not public health experts, to determine whether it adequately fits the criteria of "extreme urgency".

The export of generic drugs while under patent in Australia (for example, to assist a public health crisis in a neighbouring country) is prevented under article 17.9.6. This provision prevents Australian generic manufacturers from supplying a drug to developing countries that have issued a compulsory licence over the drug but do not have the necessary domestic manufacturing capacity and have thus made use of the Decision on the Implementation of Paragraph 6 of the Doha Declaration on the TRIPS Agreement and Public Health. ${ }^{66}$ This provision is likely to also prevent the free flow of therapeutic products between Australia and New Zealand under the new joint regulatory regime, despite that being one of the aims of the scheme. ${ }^{67}$

Article 17.9.8 of the AUSFTA locks the parties into the enhanced protectionist patent terms (an extra five years maximum) where there have been delays in issuing patent approval. One of the main areas of difference between the patent laws of Australia and New Zealand is the patentability

64 Ellen 't Hoen "TRIPS, Pharmaceutical Patents and Access to Essential Medicines: A Long Way from Seattle to Doha" (2002) 3 Chi J Int'l L 27, 52-53.

65 F M Abbott "The TRIPS-legality of measures taken to address public health crises: Responding to USTRState-industry positions that undermine the WTO" in DL Kennedy and JD Southwick (eds) The Political Economy of International Trade Law (Cambridge University Press, Cambridge, 2002) 311-348.

66 WTO Decision on the Implementation of Paragraph 6 of the Doha Declaration on the TRIPS Agreement and Public Health (WT/L/540, Geneva, 2003).

67 Australia New Zealand Therapeutic Products Authority Rationale for the Joint Scheme (Fact Sheet, December 2003). 
of methods of medical treatment for humans. Australia allows methods of medical treatment to be patented, ${ }^{68}$ while New Zealand's Court of Appeal has recently reaffirmed that methods of medical treatment are excluded from patentability. ${ }^{69}$

\section{F The Blood Products Problem}

The sixth problem relates to blood products. The establishment of the ANZTPA and the undertaking by Australia and New Zealand to include within it the regulation of blood products may have significant ramifications for New Zealand through Australia's obligations under AUSFTA to review its current plasma fractionation contract and to set aside the requirement that imported products demonstrate significant clinical advantage. Supply of blood and blood products may be delayed or interrupted and the safety of manufactured products may be reduced.

Currently both Australia and New Zealand are largely self-sufficient in their supply of fresh blood. ${ }^{70}$ Donations in both countries are collected from non-remunerated volunteers, by the Australian Red Cross Blood Service (ARCBS) and the New Zealand Blood Service (NZBS). ${ }^{71}$ Unpaid donations are well established to be a safer source than those from paid "donors". ${ }^{72}$

CSL Limited has an exclusive contract with the Australian Government, the Plasma Fractionation Agreement (PFA), to provide all of Australia's fractionation services, and is also the national provider of fractionation services to New Zealand, Malaysia, Hong Kong and Singapore. ${ }^{73}$ New Zealand sends 38,500 kilograms of plasma for fractionation annually to Australia for processing by CSL Limited, which is then returned to New Zealand as manufactured product. ${ }^{74}$

Chapter 15 of the AUSFTA ("Government Procurement") initially specifically excludes plasma fractionation. In an exchange of side letters, however, Australia agreed to complete a review of the PFA by January 2007, with the view to terminating CSL's contract and opening to tender, to United States companies, Australia's plasma fractionation. ${ }^{75}$ The terms of this side letter are set out

68 Anaesthetic Supplies Pty Ltd v Rescare Limited (1994) 122 ALR 141 (FCA).

69 Pfizer v Commissioner of Patents (2004) 60 IPR 624 (CA).

70 Australian Department of Health and Ageing Review of Australia's Plasma Fractionation Arrangements (Canberra, 2006).

71 Australian Red Cross Blood Service "Your Guide to Giving Blood" < http://www.donateblood.com.au > (last accessed 10 August 2006).

72 P Volkow and others "Paid plasma donation and risk of blood-borne diseases in blood-product recipients" (2001) 358 Lancet 2001, 2002.

73 National Blood Authority Annual Report 2003-04 (Canberra, 2004) 28.

74 CSL New Zealand Ltd "Plasma in Process Report" (11 April 2005) 3, available at <http://www.csl.co.nz> (last accessed 30 August 2006).

75 AUSFTA, above n 2, annex 15-A, s 5: Services: Schedule of Australia. 
below. ${ }^{76}$ One United States company in particular, Baxter Healthcare, has shown considerable interest in Australian plasma fractionation, lobbying the Australian Government during trade negotiations to abandon the PFA and open the service to tender. ${ }^{77}$ If the review finds in favour of an open tender process for Australia's plasma fractionation (as the Australian Government is obliged to recommend), there are significant potential consequences for New Zealand's blood supply.

First, if CSL Ltd is no longer processing Australia's plasma, it may no longer be able to provide a cost-effective service to New Zealand, forcing New Zealand to send its plasma further afield. Malaysia, Singapore and Hong Kong may be similarly affected. Secondly, New Zealand may also be required to open its own processing arrangements to tender, or will be under added pressure to do so in their own trade negotiations with the United States. Thirdly, according to the chairman of

76 AUSFTA Exchange of Letter Agreement on Blood Plasma and Blood Fractionation Services between United States Trade Representative Ambassador Robert Zoellick and Australian Minister for Trade Mark Vaille, 18 May 2004. This side letter forms an "integral part of the Agreement"; see the final paragraph. The side letter states:

- Any contract with a central government entity of Australia for blood fractionation services in effect on the date of entry into force of the Agreement shall conclude no later than 31 December 2009, or earlier if Australia deems it appropriate.

- Australia shall undertake a review of its arrangements for the supply of blood fractionation services that shall conclude no later than 1 January 2007. The Commonwealth Government will recommend to Australia's States and Territories that future arrangements for the supply of such services be done through tender processes consistent with chapter 15 (Government Procurement) of the Agreement.

- Should the Commonwealth and State and Territory governments reach agreement to make future arrangements for the supply of blood fractionation services through tender processes consistent with chapter 15, Australia shall withdraw its annex 15-A, section 5 reservation regarding the procurement of such services.

- A Party may require any producer of blood plasma products or supplier of blood fractionation services to fulfil requirements necessary for ensuring the safety, quality, and efficacy of such products. Such requirements shall not be prepared, adopted, or applied with a view to, or with the effect of, creating unnecessary obstacles to trade.

- A Party may require that blood plasma products for use in its territory be derived from blood plasma collected in the territory of that Party.

- Australia confirms that it will not apply any requirement for an applicant for approval of the marketing and distribution of a United States blood plasma product to demonstrate significant clinical advantage over Australian produced products.

- $\quad$ Article 21.2(c) (Scope of Application) of the Agreement shall apply to paragraphs 1 through 6.

77 C G Tsonis "Baxter Healthcare Submission to the Senate Select Committee on The Free Trade Agreement Between Australia and the United States of America 2004" (6 January 2006), available at $<$ http://www.aph.gov.au> (last accessed 18 August 2006). 
NZBS, "the advent of the Trans-Tasman Joint Regulatory Agency has the capacity to significantly influence the framework and standards under which the NZBS operates". ${ }^{78}$

The NZBS also expects a significant increase in its costs of compliance with the new ANZTPA, and reduced interaction between NZBS and the regulating authority, compared with what it currently enjoys with MedSafe. Concern has been raised that regulations will be imposed, rather than developed through an interactive process between the blood service and the new regulator. ${ }^{79}$

A key role of the NZBS is to maintain the national supply chain of blood and blood products. This capacity will be diminished should the tender for plasma fractionation services in Australia be opened, reducing ability to ensure rapid delivery to areas in need. Distance, reduced potential for continued quality assurance and loss of the chain of supply means that blood products may not be available when required, their safety may be reduced and their origins more difficult to trace. If there were to be a significant disaster where large quantities of blood and derived products are required, there will be increased delay in supply to New Zealand.

Some limited products (for example, clotting agents) are imported by Australia and New Zealand, but only when significant clinical superiority to local products has been demonstrated. However, in the exchange of letters with the United States, Australia agreed to set aside requirements of demonstrated clinical improvement in imported products, opening the door to more, potentially less safe products.

Blood products imported from the United States are often considered potentially less safe than those manufactured from donors in Australia and New Zealand because, among other reasons, "donors" in the United States are often paid (up to US\$200 per month legitimately, or more if they attend different collection centres and donate more often than recommended). ${ }^{80}$ The setting aside under AUSFTA of the clinical improvement requirement potentially reduces New Zealand's capacity to ensure safety in its blood products. The value of safe blood from Australia and New Zealand may be such that a special market is created overseas for that proportion siphoned off after fractionation.

The advent of the ANZTPA could potentially lead to Australia and New Zealand being treated as a single, larger source of blood and plasma and a single market in buying back blood products, with no differentiation between the two. If the high standards of each country are maintained, this may not be a safety issue, although it could become a political one if one country's donations were

78 New Zealand Blood Service Statement of Intent 1 July 2005 - 30 June 2006 (Auckland, 2005) 2.

79 New Zealand Blood Service, above n 78, 25.

80 See P Volkow, Y Lopez-Vidal, R I Amieba, M Hernandez "Paid Donation and Risk of Blood-borne Disease in Blood-product Recipients" (2001) 358 Lancet 2001; C L Van der Poel, E Seifried, W P Schaasberg "Paying for Blood Donations: Still a Risk" (2002) 83 Vox Sang 285. 
perceived to be shoring up the blood supply of the other. With the ANZTPA, New Zealand may find itself tied to Australia's obligations under the AUSFTA, and become an unwitting participant in the global blood trade.

\section{G Medical Devices Issues}

Sponsors of medical devices who are legally supplying those products in Australia or New Zealand prior to commencement of the joint scheme will qualify for a transitional approval, to be known as an interim product licence. This licence will authorise the continued supply of the medical device, in the jurisdiction in which it was previously being lawfully supplied, for the duration of a defined transition period.

A major AUSFTA concern here for New Zealand is that annex 2C(4), with its "fast track" obligations, refers to "medical products" and not merely pharmaceuticals. Currently in New Zealand, medical devices ${ }^{81}$ do not need to be approved by Medsafe before they are marketed to consumers. There exists a set of established standards with which manufacturers are required to comply, but Medsafe's role with respect to compliance is limited to "market surveillance and dealing with safety issues as they emerge rather than preventing sub-standard devices from being used". ${ }^{82}$ While the adoption of the Australian-style system for the regulation of medical devices before marketing approval is granted represents a positive for New Zealand consumers, the absence of an existing regulatory system makes it more difficult for New Zealand to resist being subjected to these fast-track obligations.

Similarly, there is the potential for the "innovation" principles in annex $2 \mathrm{C}(1)$ of the AUSFTA, which apply to pharmaceuticals, to be extended to apply also to medical devices in Australia and New Zealand. Thus, the integration of medicines and medical devices under the ANZTPA, in conjunction with the application of the AUSFTA, may affect the cost-effectiveness evaluation of medical devices. The effect of prioritising "innovation" over cost-effectiveness of medical devices

81 "Medical Devices" includes products used for diagnosis, prevention, monitoring or treatment of disease, injury or handicap; for investigation, replacement or modification of the anatomy or a physiological process; or for the control of conception. In contrast to medicines, they deliver their intended effect through nonpharmacological means (eg mechanical, electrical, radiation). Medical devices range from very low risk products such as bandages to high-risk products such as implantable heart valves. In contrast to most developed countries, New Zealand does not currently require medical devices to be approved before being marketed. (A small subset of devices (condoms, pregnancy test kits and devices containing medicinal substances) does need approval from Medsafe before they are sold in New Zealand, to ensure they meet appropriate standards.)

82 Ministry of Health National Interest Analysis on the Agreement between the Government of Australia and the Government of New Zealand for the Establishment of a Joint Scheme for the Regulation of Therapeutic Products (Wellington, March 2004) 3. 
will become increasingly important as nanotechnology research spurns a wide range of expensive but innovative nanomedical devices. ${ }^{83}$

Additional concerns in this area are corporate-led international harmonisation processes in safety and efficacy evaluation of medical devices that appear to undermine the precautionary principle by shifting the burden of proof to public authorities post marketing approval. ${ }^{84}$

\section{H Dispute Resolution Mechanisms}

The role in the ANZTPA of AUSFTA annex 2C(4), the "evergreening" article 17.10.4 and the requirement to recommend tendering for blood fractionation becomes more problematic for New Zealand public health policy when it is considered that they are linked to the dispute resolution mechanisms in chapter 21 of the AUSFTA through a non-violation nullification of benefits (NVNB) provision in article 21.2(c). NVNB provisions are much despised in international trade law settings, particularly by those countries and non governmental organisations seeking to expand access to essential medicines. ${ }^{85}$ NVNB provisions are really a supercharged mechanism of commerciallyfocused treaty interpretation, drawing the focus toward expectations of profit and away from actual text. ${ }^{86}$ They allow dispute resolution proceedings to be commenced where only the "spirit" of the treaty has been broken. Developing and developed countries alike have fought for and succeeded in placing a moratorium on the invocation of such causes of action under TRIPS. ${ }^{87}$

In European Communities - Measures Affecting Asbestos and Asbestos-Containing Products the WTO Appellate Body agreed with the panel in Japan - Measures Affecting Consumer Photographic Film and Paper that NVNB articles "should be approached with caution and should remain an exceptional remedy". ${ }^{88}$ It also, however, rejected the interpretation that they applied only to

83 See S M Moghimi, A C Hunte, and J C Murray "Nanomedicine: Current Status and Future Prospects" (2005) 19 FASEB 311.

84 Global Harmonization Task Force "Working Towards Harmonization in Medical Device Regulation" $<$ http://www.ghtf.org> (last accessed 10 August 2006).

85 See Council for Trade-Related Aspects of Intellectual Property Rights Minutes of Meeting Held on 25-26 and 28 October 2006 (IP/C/M/49) 42. See also South Centre and The Centre for International Environmental Law (CIEL) "IP Quarterly Update: First Quarter 2004" 1, available at <http://www.ciel.org> (last accessed 30 August 2006).

86 K J Harvey and others "Will the Australia-United States Free Trade Agreement Undermine the Pharmaceutical Benefits Scheme?" (2004) 181 Med J Aust 256, 258.

87 A five-year moratorium was originally written into the text of TRIPS in article 64.2, and has been extended by the WTO membership three times. A large majority of WTO members, including the EC and Canada, support the position that NVNB complaints are not applicable under TRIPS. See WTO Council for TRIPS Minutes of Meeting (IP/C/M/48, 14-15 June 2005) 34.

88 Japan - Measures Affecting Consumer Photographic Film and Paper (31 March 1998) WT/DS44/R para 10.37 (Panel, WTO); European Communities - Measures Affecting Asbestos and Asbestos-Containing Products (12 March 2001) WT/DS135 para 186 (Appellate Body, WTO) [European - Asbestos]. 
"commercial measures". Instead, the Appellate Body held it applied to "measures which affect trade in goods" and which "have a commercial impact". 89 This meant that health-related measures could fall within such provisions, in rare circumstances such as where such a measure was not impliedly or expressly addressed by either party during negotiations. It explicitly left open the question of whether a party could have "reasonable expectations" for NVNB purposes in relation to "continued market access for products which are shown to pose a serious risk to human life or health". ${ }^{90}$

It seems highly unusual that New Zealand, by agreeing to join the ANZTPA, should potentially find itself caught up in an AUSFTA trade dispute over whether the legitimate expectations of the United States (in respect of, for example, TGA obligations in annex 2C(4) and article 17.10.4) have been impaired or nullified by "measures" implemented by the ANZTPA. Major issues for New Zealand sovereignty are involved. Under the AUSFTA dispute resolution process, the ultimate meaning of pharmaceutical "innovation" in annex $2 \mathrm{C}(4)$ and $2 \mathrm{C}(1)$, or the obligations imposed on the TGA (and the ANZTPA) by article 17.10.4 may be determined by a three person panel of trade lawyers appointed under AUSFTA chapter 21. However, interpretations of such obligations may be resolved long before this, in the shadow of industry threats of cross retaliation in other trade sectors, such as manufacturing and agriculture, or massive compensation claims.

AUSFTA annex 2C(3) establishes a "Medicines Working Group" between health officials from each country. The Medicines Working Group is ostensibly prohibited from promoting discussion and mutual understanding on the issues mentioned in annex $2 \mathrm{C}(4)$. "Innovation", however, is clearly at the top of the agenda for the Medicines Working Group. ${ }^{91}$ Its definitions and applications of that concept will undoubtedly flow through to the ANZTPA if it inherits the TGA's AUSFTA annex $2 \mathrm{C}(4)$ obligations.

\section{CONCLUSION}

The ANZTPA has the potential to become a bridgehead for related AUSFTA obligations applying in New Zealand in at least eight major areas. Collectively these obligations (and the corporate lobbying associated with them) could change the landscape of public health policy in New Zealand without the capacity of its people to readily contravene them through traditional democratic processes.

Late in September 2004 eight major public health organisations and many of Australia's most eminent public health experts signed an open letter to the leaders of both major federal political

89 European-Asbestos, above n 88, para 189.

90 European-Asbestos, above n 88, para 190.

91 United States Department of Health and Human Services "Australia-US Medicines Working Group Holds First Meeting" (14 January 2006), available at <http://www.globalhealth.gov> (last accessed 10 August 2006). This article and the accompanying photograph represent all that is publicly available about the composition and terms of reference of the Medicines Working Group. 
parties. It called for Australia to place on record at the time of ratifying the AUSFTA a unilateral interpretive declaration over those ambiguities in its text most likely to adversely affect the PBS and over which there was a clear difference of opinion between United States and Australian authorities. $^{92}$ Soon afterwards, the Australian Parliament passed amendments to the AUSFTA implementing legislation designed to prevent the practice of brand name patent "evergreening" occurring under article 17.10.4. ${ }^{93}$ Given the context, this legislation can be regarded as being the equivalent of a unilateral interpretive declaration concerning the pharmaceutical provisions in the AUSFTA. The USTR reserved United States rights over these amendments in the final exchange of letters over the AUSFTA. ${ }^{94}$ His Australian counterpart, in the same exchange of letters, acknowledged that a difference of opinion had arisen but that this was not significant enough to prevent the entire deal from proceeding. ${ }^{95}$ If New Zealand inherits the TGA's AUSFTA article 17.10.4 obligations by entering the ANZTPA, a major issue will be whether it also inherits Australia's anti-evergreening protections.

An intended consequence of PhRMA's efforts, however, may be that the AUSFTA pharmaceutical provisions open the door to a broader discussion by regulatory authorities in the United States and New Zealand on the type of research necessary to establish that a pharmaceutical is truly innovative. A crucial part of such research, for example, will be the extent that a claim for pharmaceutical innovation under the AUSFTA requires proof (as required by the words of annex $2 \mathrm{C}(1)$ ) of a medicine's benefit to public health through comparative affordability and objectively demonstrated therapeutic significance.

One policy suggestion for the preservation of both the integrity of its safety, quality and efficacy regulatory processes in the face of "fast track" pressures from industry and Pharmac costeffectiveness systems under stress from the corporate lobbying principle of "innovation," is for New Zealand to include provisions fostering capacity building of the relevant experts in bilateral and regional trade agreements. Such a provision might read along these lines:

Committee on the Safety and Cost-Effectiveness of Medicines and Medical Devices:

The Parties hereby establish this Committee, comprising relevant government officials and expert advisors, whose objective shall be to promote discussion and mutual understanding with a view to enhancing and developing techniques of and research related to safety and cost-effectiveness evaluation of medicines and medical devices.

92 Public Health Association of Australia, to the Australian Prime Minister and Leader of the Opposition "Leading Health Experts Say Ambiguities in Trade Deal Put PBS at Risk" (27 September 2004) Open Letter.

93 US Free Trade Agreement Implementation Act 2004 (Cth), sch 7, cl 6.

94 Zoellich-Vaile Letter, above $\mathrm{n} 27$.

95 Zoellich-Vaile Letter, above n 27. 
Such a provision would not breach TRIPS obligations or inhibit the capacity of intellectual property protection to foster local innovation. ${ }^{96}$

New Zealand appears eager to secure a free trade deal with the United States. ${ }^{97}$ The United States, however, is showing some reluctance. ${ }^{98}$ Australia, through the AUSFTA, appears to have gained some trade concessions in agriculture and manufacturing by conceding to United States pharmaceutical industry demands to include "fast tracking" for innovative medical products (annex $2 \mathrm{C}(4)$ ), the "evergreening" notification process (article 17.10.4) and tendering for blood fractionation and the prohibition on parallel importation (article 17.9.4). It makes little economic sense for New Zealand to risk giving these bargaining chips away via the ANZTPA, particularly when the possibility of a United States-New Zealand trade deal still exists.

96 See T A Faunce "Toward a Treaty on Safety and Cost-Effectiveness of Pharmaceuticals and Medical Devices: Enhancing an Endangered Global Public Good" (2006) 2 Globalisation and Health 5.

97 Hon Phil Goff MP, Minister for Trade Negotiations "Goff to US for Forum, Trade and Defence Talks" (18 April 2006) Press Release.

98 See "US-NZ FTA Prospects Dip" (25 January 2006) Radio NZ, quoting Rob Portman, United States Trade Representative Ambassador, who told a media briefing in Washington on 25 January 2006 that the United States would rule out talking to small economies, which would include New Zealand. See also Bilaterals.Org $<\mathrm{http}: / /$ www.bilaterals.org $>$ (last accessed 10 August 2006). 
